\title{
GEN $Z$ PERCEPTIONS AND EXPECTATIONS UPON ENTERING THE WORKFORCE
}

\author{
ALINA ELENA MĂRGINEAN \\ West University of Timișoara, Faculty of Sociology and Psychology
}

(C) 2021 Alina Elena Mărginean

This is an open access article distributed under the Creative Commons Attribution-NonCommercial-NoDerivs license (http://creativecommons.org/licenses/by-nc-nd/3.0/)

DOI: $10.1515 /$ eras-2021-0003

\begin{abstract}
This article focuses on examining Gen Z-ers' opinions and expectations regarding their present or future jobs, as well as their views on their future careers. The exploratory study performed on members of this cohort revealed, among others, that Gen Z-ers appreciate a secure job, financial stability, and prefer working for big companies. They choose jobs which reflect their passions and look for informal and relaxed environments, where they can have their own well defined office space. This cohort wishes to be mentored at work and is brutally aware that success must come with career-long learning. Despite being said to be digital natives, they feel the need to bond with colleagues and to freely speak their mind.
\end{abstract}

\section{Keywords}

Generation Z, labour market entry, career expectations, job expectations

\section{Introduction}

The global media coverage, as well as the empirical and academic research interest in the workforce traits of Millennials, has set in motion a phenomenon that also affects Generation $Z$. To shed light on this new cohort is on the agendas of employers, governments, and marketers, even more now, that Gen $\mathrm{Z}$ has already entered the labour market.

Born beginning with the year 1995 (Adecco, 2015; Bartold, 2015; Fedock, 2017; Black et. Al, 2017; Accounting Principals, 2017; Villa \& Dorsey, 2017), this is the generation which, together with the Millennials (Generation Y), will soon make up most of the workforce and consumers.

Managers, realizing that ensuring sustainable business targets requires strategic skill management (Davies, 2011; Hecklau, 2016; Schwartz, 2017), are beginning to emphasise career and learning strategies (Schwartz, 2017), focusing on improving and/or reshaping the skills set framework they operate on.

A Bloomberg analysis on United Nations data concluded that the global population share of Generation Z has, in 2019, already surpassed that of the Millennials. It is assumed that Gen $\mathrm{Z}$ comprised 2.47 billion people, or $32 \%$ of that year's population, while Millennials accounted for 31.5\% (Miller \& Lu, 2018; Wood, 2018). It is to be noted that the demarcation used by the UN is the years 2000/2001, contrary to the years 1995/1996 held by general perception. According to the same UN data, Gen Z accounted for $18 \%$ of Europe's total population. In Romania, between 2015 and 2018, this cohort of around 3.5 million persons made up $17 \%$ of the total population. $49 \%$ of them are women. Less than half $(47.6 \%)$ of 
Romania's Gen $\mathrm{Z}$ population lived in urban areas in 2015, which is 6 percent less than the national urban population (INSSE, 2018).

It is expected that Gen $\mathrm{Z}$ will make up $27 \%$ of the global workforce by 2025; an average Gen Z-er is projected to work 17 different jobs, experience 5 career shifts and change 15 homes during his/her entire life (McCrindle, 2018).

Additionally, today's job market is more diverse and heterogeneous than ever, bringing together representatives of four or five distinct generations (Accounting Principals, 2017). Shortly enough, Millennials and Gen Z-ers will, naturally, make up most of the workforce.

Older generations are searching for ways to attract youngsters, to, on the one hand, help themselves adapt, and, on the other hand, to shape younger people and bring them closer to what is familiar to them. These approaches are innate to humans, belonging to 'cognitive biases': predilections or prejudices not belonging to rational thinking (Tversky \& Kahneman, 1974). Their consequences include irrationality and erosion of reality perception (Ariely, 2008). The concept of dividing the population by generations may belong to biases such as the fundamental error of attribution or group attribution error. The former describes the tendency to evaluate an individual in terms of their character and not in terms of the external factors which could have shaped that character; the latter describes the practice of judging an entire group by the actions of one particular member (Bicchieri, 2017; Hamill et al., 1980). There are, however, certain circumstances in which they can help us make quicker decisions in cases of uncertainty (Tversky \& Kahneman, 1974).

Consequently, talking about generations can be a useful endeavour, as managers, companies or HR specialists are in need of a collection of general traits of Gen Z-ers to help them adapt to the new wave of employees (Twenge, 2010). The same might apply to marketing or sales specialists, whose better knowledge of the younger generation may help tailor advertising campaigns in order to boost revenues and profits.

For a preliminary assessment of Gen Z's expectations and perceptions about career and the workplace, the following research questions were proposed: [1] What kind of organizational environment do Gen Z-ers prefer? (by which means physical place, management and personal interactions); [2] What are their expectations of a good job?; and [3] How do they project their professional life to be going to be like?

\section{Literature Review - Gen $Z$ traits \& career expectations}

Generation $\mathrm{Z}$ has become of most interest a few years ago, both in media and research fields. A short literature review on its traits and perceptions regarding the labor market can be found below.

Some employers believe that Gen Z-ers will, on average, enter their first internship earlier than other generations, at 16 years old (Jenkins, 2015b; Villa \& Dorsey, 2017). A more recent study disproves these statistics, showing that half of all teenagers have not had their first job yet (Twenge \& Park, 2017).

In the USA and Canada $41 \%$ of Gen Z-ers leant towards middle-sized organisations, and 38\% towards corporations (Half, 2015). In Romania however, most (42\%) opted for corporations, $21 \%$ an entrepreneur's company, and only $19 \%$ would head towards entrepreneurship or the public sector (Ernst \& Young, 2017).

Generation $\mathrm{Z}$ is also characterised as entrepreneurially minded, innovative, more open towards business and international activities than previous generations, thanks to their bond with the digital (William 2,016). 32\% expects to hold a managerial position within 5 years of graduating (Half, 2015). Opinions regarding this cohort's willingness to start an own venture are divided. Robert Half projects a percentage of 20\%, Deep Patel $72 \%$, while the Accounting Principals study puts forth a possibility 55\% greater than that of Millennials (Half, 2015; Patel, 
2017, Accounting Principals, 2017).

Entrepreneurship, however, implies a high appetite towards taking certain risks, and other authors (or, in some cases, the same) argue that Generation $\mathrm{Z}$ is more inclined towards stability and security, being more temperate and calculated, more risk-averse than Millennials (Jenkins, 2015; Weller, 2017).

$22 \%$ of Gen Z-ers wish their professional life to be 'an expression of their personalities' (Arnett, 2004, 143; Kantar, 2017). Action-oriented, eager to innovate and to impact the world (Kingston, 2014; Jenkins, 2015a), Gen Z-ers are creative and open to improvement and change. The same Robert Half who praises this generation's entrepreneurial tendencies reminds that for them, globally, good pay and job security rank on the second and fourth place, respectively. Only $13 \%$ of young people would prefer working in start-ups (Half, 2015). In Romania, for example, $80 \%$ of interviewed Gen Z-ers opt to place job security on the higher second tier, as opposed to its international relegation on the fourth (Ernst \& Young, 2017).

On the other hand, Generation $\mathrm{Z}$ is driven by money and security, believes everything to be possible and achievable, and prefers instant gratification (Patel, 2017; Accounting Principals, 2017) [n. a. multiple authors believe the same about Millennials]. Opinions regarding fundamental traits of the generations are so diverse that other authors argue, on the contrary, that Generation $\mathrm{Z}$ is less dreamy, fears for tomorrow and has more modest expectations than Millennials, as a result of having lived in a post-9/11 era and having known the 2008 Recession (Tulgan, 2013; Jenkins, 2015b; Patel, 2017) [n.a. The same argument can be brought for Millennials].

Regarding entering the workforce, $64 \%$ of responders in the USA and Canada rate shortterm career opportunities as highly important. In the case of Romania, 94\% of responders consider promotion and training opportunities within their company as the most important, as does the rest of the world. Workplace stability comes up in second place (80\%), as opposed to fourth in North America. Tied for places 3 and 4, with 79\%, are fairness of pay and promotion, and respect for personal privacy respectively, showing flexibility regarding time and place of work. Furthermore, $60 \%$ of Generation $\mathrm{Y}$ and $\mathrm{Z}$ responders consider an employer's inability to offer training and growth contracts a major drawback (Earst \& Young. 2017).

Opinions regarding communication diverge as well. Despite being digitally connected, it seems that most of Gen Z-ers prefer face-to-face communication, seeking authentic and real relationships (Half, 2015); human relationships are more important than ever to them (Tulgan, 2013). Other authors consider them much more isolated than previous generations (Weller, 2017); along with Millennials, they consider themselves lonelier and less healthy (Cigna, 2018). The $\mathrm{Z}$ cohort wish to work in a relaxed, informal or amusing environment (47\%), and they also have a preference towards flexible working hours (44\%) (Villa \& Dorsey, 2017). Gen Z members seem not to draw such a clear distinction between the workplace and personal life, which may have great consequences on the job market (Patel, 2017).

The wish to be mentored by the manager $(21 \%)$ also correlates to the expectation of being guided, especially at the outset of their career (to be treated in a following section of this paper). While at first sight we might see this fact as contradictory to another conclusion of the same study-their wish to be independent and stronger entrepreneurial thinking (Half, 2015) - a closer interpretation shows that this entrepreneurial thinking offers them the maturity necessary to accept guidance, thus creating the expectation of having the know-how required in their job description at their disposal. Additionally, Paul McDonald, Executive Director of a renowned consulting firm, emphasises Gen Z's openness to receiving, as well as giving, constant feedback (Half, 2015). This aspect, perhaps less visible in Romania than in the USA, may vary widely from one company's culture to the next. Companies can make the most of this generation's desire to learn rapidly, by creating an adequate workplace and organizational 
structures through mentoring, coaching, shadowing and, most importantly, authentic, and honest feedback (Tulgan, 2013; Half, 2015; Accounting Principals, 2017; Ronnie, 2017).

Generation $\mathrm{Z}$ is seen as competitive (Patel, 2017), determined to leave its mark on the world (Jenkins, 2015a), pragmatic, independent and obstinate (Accounting Principals, 2017).

Further still, considering that most of the jobs are based upon human interaction, one cannot neglect Generation Z's perception regarding this subject. 38\% appreciate the direct manager's sincerity and integrity the most, $21 \%$ his ability to coach, while compassion and intelligence rank the lowest among the preferences (7\% and 6\% respectively) (Half, 2015). In Romania, good communication and respect shown by the direct manager prove to be major factors in retention. To these one might add traits such as keeping promises or acknowledging one's own merits and point of view (Earst \& Young, 2017). These results are correlated to this generation's expectations regarding career opportunities and the role of the workplace in its life.

Generation $\mathrm{Z}$ seems to be shifting its approach to professional life, tending to evaluate 'the role a workplace plays in the context of their personal life and n,ot that of the individual within the company they work for' (Bruce Tulgan, quoted in Half 2015). This is why it is no surprise that, unlike their parents or grandparents, they expect to work for four companies throughout their life (Half, 2015) or change 17 jobs (McCrindle, 2018). Their entrance into the job market, additionally, is delayed compared to the previous generations, according to an extensive study of the USA population (Twenge \& Park, 2017). We expect Generation Z to experience a 60-to-70-year long career, with 4.5 years, on average, spent in one single job (Gratton, 2016); 38\% of its members expect to work during their college studies (Villa \& Dorsey, 2017).

Generation $\mathrm{Z}$ witnessed, as children or teenagers, the hardships endured by their parents during the 2008 Recession. Consequently, its members expect to need to work harder than previous generations in order to succeed-77\% hold this stance (Half, 2015).

The $\mathrm{Z}$ cohort seems to be more aware than its predecessors that lifelong learning and continual development is paramount to staying relevant in the job market (Jenkins, 2015b; Iorgulescu, 2016; Patel, 2017; Accounting Principals, 2017).

Generation $\mathrm{Z}$ might be the most tolerant one to date, ethnically, racially, or culturally, having become truly global (Accounting Principals, 2017). The diversity it displays when it comes to social inclusion, marriage liberalisation (Kane, 2017), equality of opportunity between ethnicities, or the international workplace, will become a constant throughout Gen Z-ers' life.

$64 \%$ of them would rather work in small teams in a closed office, as opposed to the open offices used by many companies (Tulgan, 2013; Half, 2015). They are, additionally, much more oriented towards individual work than towards teamwork, as opposed to, for example, Millennials; they expect a team with widely specialised members and an undeveloped hierarchy-a 'flat'" organisation (Patel, 2017; Accounting Principals, 2017).

\section{Data and Methods}

This research aimed to be an exploratory one. It integrated a quantitative method, which operated data collected from members of Gen Z using a self-applied online survey, CAWI - Computer Assisted Web Interviewing. The survey was randomly distributed to

\footnotetext{
* 'Flat organisation' - an organisation in which middle management has been eliminated, and top management is in direct contact with the organisation. The number of positions and managers is usually limited, members are seen as equals, and the workflow is entrepreneurial.
} 
students from Timișoara and Bucharest, Romania.

The inquiry consisted of 25 questions: the types of questions were single-selection, multiple-answer, and ranking or rating various statements. Data was processed using Microsoft Excel.

\section{Results and Discussions}

A total of 69 members of Gen $\mathrm{Z}$ answered the survey. Being an exploratory study, this does not claim to be wholly representative of this cohort in Romania. Its scope was a preliminary assessment of people's perceptions and desires, in a broad, descriptive, and exploratory way. Therefore, the results should be interpreted with caution.

$71 \%$ of the respondents of this survey were females. The highest education level completed for $81 \%$ of the Gen Z-ers answering this survey was high school, while $14.5 \%$ had completed their bachelor's degree. This means that the vast majority of this survey's respondents are female university students.

The level of experience on the labor market was assessed using two single-selection questions. The first one asked participants to indicate the type of their last job, if any. Almost half of them (around 45\%) declared having had at least one job experience, $42 \%$ of the respondents lack any contact with the job market, and very few of them are entrepreneurs or freelancers (see Graph 1).

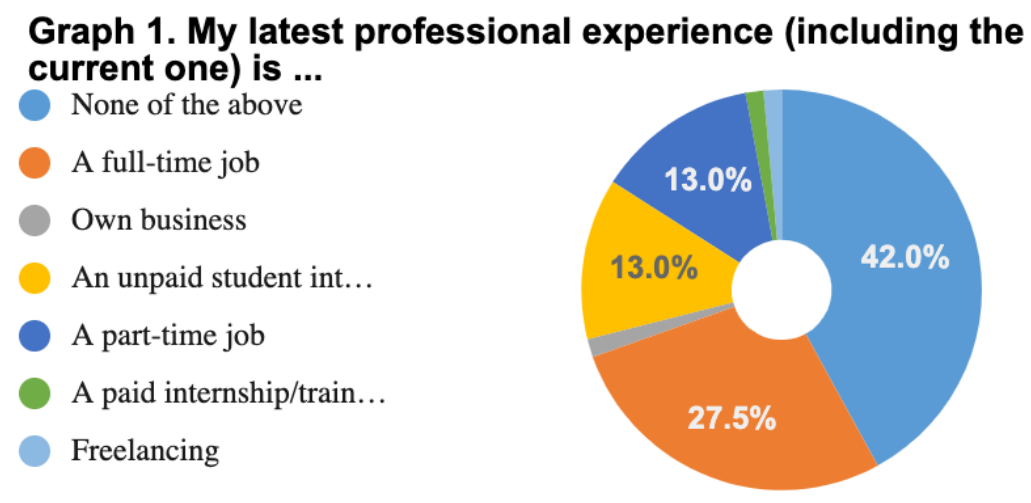

The second question asked respondents to indicate the age of their first financially rewarded professional experience. Around 7\% reported having begun earning money between 14 and 15 years of age, and almost $22 \%$ of them when 16-17 years old. In Romania, the legal age for entering the labor market is 16 , and the official minimum age for drinking alcohol, having a driving licence, or voting is 18 . Therefore, 18 is symbolically regarded as the final milestone to legal adulthood- $11.6 \%$ of the Gen Z-ers who answered this survey had their first job experience at this age. On the other hand, in Romania, young people usually finish high school when around 19-20 years old; it is no surprise, therefore, that almost $16 \%$ of them took up some sort of work at this age. More than a third of the respondents said they had not yet entered the labor market.

Another question asked youths to estimate the amount of time it would take them to search for their next job, regardless of whether or not they were looking for one at the moment. It seems that the majority has a moderate to optimistic outlook, as $31.5 \%$ of them estimated it would take them between 1 and 3 months, and 20.4\% said less than a month. However, on the opposite side, a significant $20 \%$ of the respondents think they will spend more than a year in search for their next professional endeavour.

In order to answer the first problem posed in this paper, which is: [1] What kind of 
organizational environment do Gen Z-ers prefer?, several questions were formulated.

The broad scope of the next question was to identify Gen Z's preference regarding the type of organization they wanted to work for in the future. This question also had two secondary objectives: (1) to differentiate between preferences towards working for the public, private or non-profit sector respectively, and (2) to identify the predisposition towards entrepreneurship. $29 \%$ of the respondents declared that they wish to work for a big, corporate-like company, while almost $16 \%$ opted for a small start-up company. $20 \%$ of the respondents stated their wish to start or have their own company; $18 \%$ preferred the public sector. These findings broadly align with the results provided by an Ernst \& Young study in Romania (2017) and with Robert Half's (2015) findings.

Interestingly, when comparing the Gen $\mathrm{Z}$ members who have not had any work experience yet with those who have, a much greater proportion out of the first group wish to work in the public sector-27\% vs. $14 \%$. One notices yet another noticeable difference when it comes to entrepreneurial perspective: only $10 \%$ of those without previous experience would like to run their own business, as opposed to $30 \%$ of the rest. However, working for a small, start-up-like company is similarly appealing for both groups, with $17 \%$ and $14 \%$ respectively.

The next question asked Gen $\mathrm{Z}$ members to evaluate several different items, using a system of points ranging from 1 to 5, meaning "not important at all" and "extremely important" respectively.

As elaborated in the literature review, some researchers opinionated that Gen $\mathrm{Z}$ desires their job to be "an expression of their personality" (Arnett, 2004, 143; Kantar, 2017). There are 2 items in the present research that also seem to support that statement (see Graph 2). 85\% of the respondents rated the statement "My work represents me" as being extremely important (5 points) or very important (4 points), while $8 \%$ were neutral (3 points). Moreover, $85 \%$ of the Gen Z-ers see liking what they do on the job as of the greatest importance, rating it with 5 points; the rest of them, $15 \%$, rated the same statement with 4 points (Graph 3 ).

Gen $\mathrm{Z}$ also seems to be extremely willing to make an impact through their jobs. Almost $61 \%$ of them marked this item as being extremely important, and $22 \%$ as important. Their action-oriented and energetic character, as described by Kingston (2014) and Jenkins (2015a), seems not to come through in this research, given that only $46 \%$ of them declared they wanted to get into the job's tasks as soon as possible once employed.

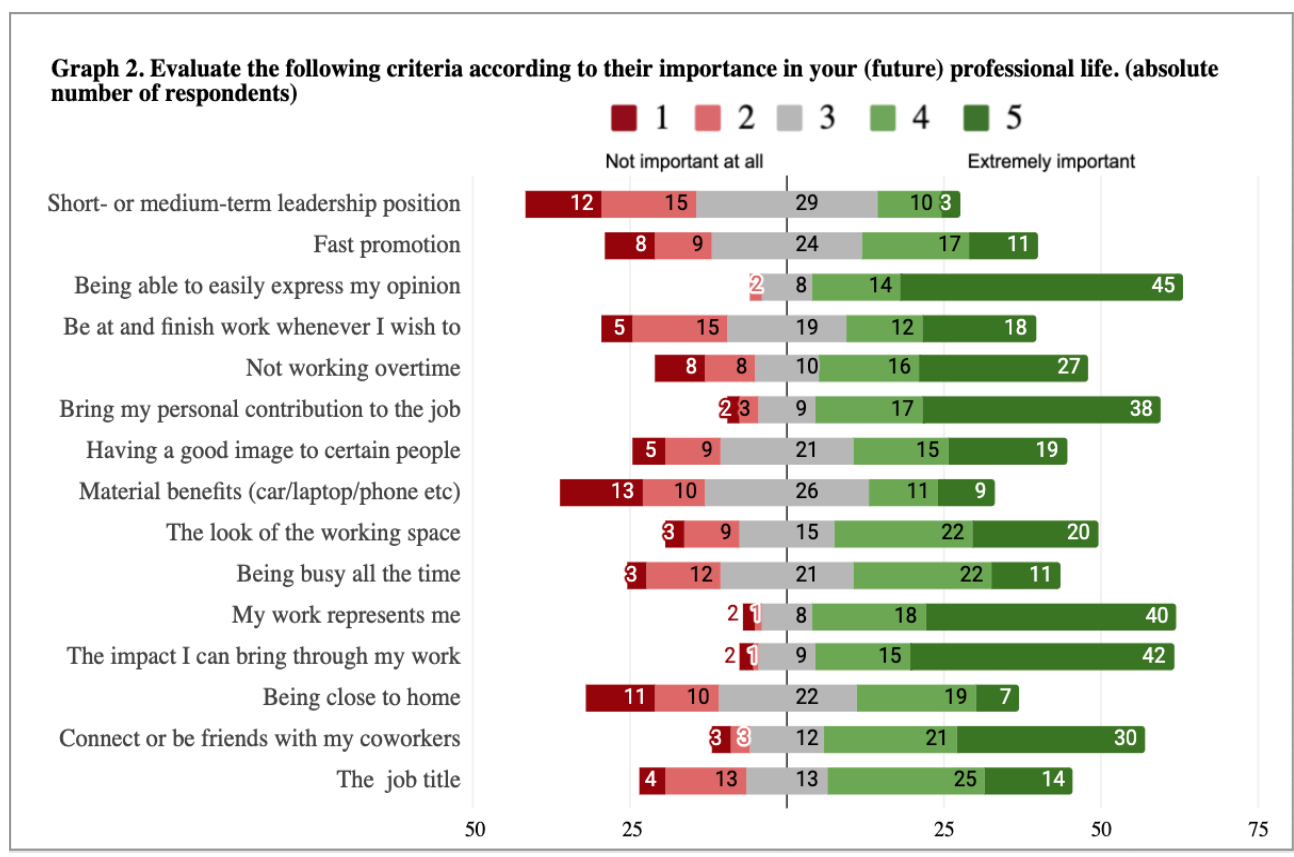


Although Gen $\mathrm{Z}$ is regarded as being a tech savvy cohort, which may prefer digital interaction over physical one (Weller, 2017), almost $74 \%$ of the respondents greatly value the possibility to bond with colleagues; this is more in line with Tulgan's opinion (Tulgan, 2013). It is of note that this measurement does not specifically mention what type of interaction Gen $\mathrm{Z}$ prefers. Moreover, $85 \%$ of them state their wish to freely speak their mind.

Almost half of this questionnaire's respondents believe that having a mentor to pass on the know-how is of extreme importance (rating it 5 points), while almost $40 \%$ rated this item with 4 points, similarly to Half's findings (Half, 2015). In the same vein, $60 \%$ of the respondents would very much wish to be encouraged even if they make mistakes (see Graph 3).

A relaxed, informal working environment was regarded as being very important by $71 \%$ of the respondents. However, fewer Gen $\mathrm{Z}$ members (49\%) wish not to have a stressful job; $30 \%$ are neutral in this matter (see Graph 3 ).

It is said that this cohort is more tolerant in more ways than the previous ones (Accounting Principals, 2017; Kane, 2017; Jenkins, 2015b). This questionnaire tackled Gen Zers' willingness to work with people of different age, gender, culture, and race. $50 \%$ of them declared being in favour of having colleagues of various ages in their team, while over a quarter of them would rather work only with people under 30 years of age. On the gender side, the vast majority, $87 \%$, state that they feel comfortable with working with either males or females. Finally, on the cultural and racial side, almost $90 \%$ of the respondents said they either enjoy or would like to have co-workers from a different country and race than them.

The opinions of Gen $\mathrm{Z}$ answerers are divided in 3 when it comes to teamwork. $36 \%$ of them would rather work individually, and $30 \%$ did not express their preference. Another question, regarding the hierarchical type of organization Gen $\mathrm{Z}$ would prefer to work for, registered almost similar percentages - 39\% favoured a "flat" company and 35\% a hierarchical one; the rest displayed no preference.

The desirable physical working environment is also of interest to this research, especially in the present global health situation. If they were to choose the location for their daily work, almost $60 \%$ of the respondents would combine remote and on-site work. Around $19 \%$ prefer working at the office, while only $9 \%$ choose complete remoteness. Another topic this study tackled is the predilection towards different types of physical offices. $45 \%$ of the respondents would rather have their own enclosed desk or workspace, while only $22 \%$ of them like coworking spaces or the open-office areas currently used by many companies.

Following the second query, [2] What are Gen $\mathbf{Z}$ expectations regarding a good job?, the next question asked Gen $\mathrm{Z}$ members to evaluate several different items using a system of points ranging from 1 to 5 , with ' 1 ' meaning "not important at all" and ' 5 ' "extremely important".

Job security is of considerable importance to Gen $\mathrm{Z}$ members. $65 \%$ of the respondents gave it 4 or 5 points (see Graph 3), which is in line with other research or opinions describing this cohort as risk-averse, oriented rather to financial and professional stability (Jenkins, 2015; Weller, 2017). Job security is ranked in 4th place in an international study; in Romania, however, 80\% of youths placed it in second place (Ernst \& Young, 2017; Half, 2015).

Financially speaking, although it is difficult to draw conclusions, one can argue that pay is of significant value, though not at the top of the list, as other authors have also mentioned (Patel, 2017; Accounting Principals, 2017). When asked to rate the importance of earning a big salary from the outset of their career, $36 \%$ of the respondents awarded it 4 points, $39 \%$ were neutral (marking it with 3 ), and only $18 \%$ considered it not that important or not important at all (see Graph 3).

On the other hand, the perspective of a solid salary in the near future is of high 
importance to Gen Z-ers. $69 \%$ of the respondents rated this matter with 4 or 5 points, $20 \%$ were neutral, and only considered it unimportant (see Graph 3). Speaking of job opportunities in the near future, two other items are worth mentioning: the possibility of being awarded a managerial spot, and to be promoted, respectively. Gen $\mathrm{Z}$ is not in a hurry to lead others, seeing that for $39 \%$ of them this matter is not of much importance, and insignificant to $42 \%$. However, a promotion is seen as more valuable, with the statistics in opposition to the previous: $40 \%$ place considerable importance on it, while $34 \%$ are not certain about it. Additionally, having one's accomplishments acknowledged is paramount for $87 \%$ of this cohort. A study by Ernst \& Young (2017) revealed that promotions and fairness are of the greatest importance to Gen Z, both globally and locally.

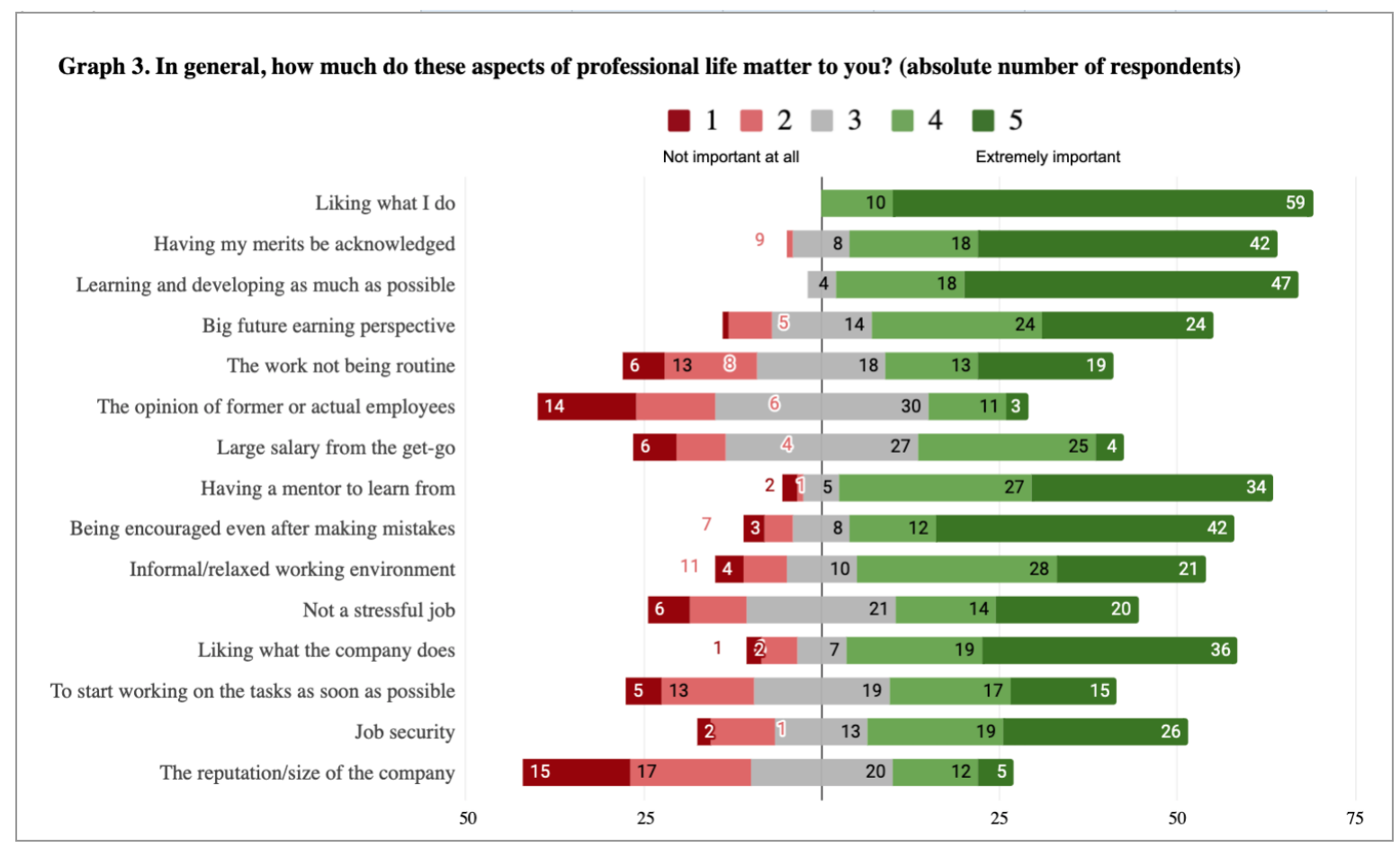

Learning opportunities on the job have also scored very high in significance for Gen $\mathrm{Z}$ members, as $94 \%$ of them have rated them as important or extremely important, in line with Ernst \& Young findings (2017) (see Graph 3).

Gen Z-ers' relationship to their direct manager is another topic worth exploring. When asked what they appreciate about their manager, $59 \%$ of the respondents declared that they do not have such a figure. Analysing the responses of the other Gen $\mathrm{Z}$ members proved to be both difficult and intriguing, possibly indicating their lack of work experience. They had the option to choose as many items as they considered applied, from a total of 11 . The most desired characteristics for a manager were: the ability to mentor/teach, intelligence, keeping promises, and acknowledging team members' merits $(26 \%)$, very closely followed by their sincerity and being close to the team (25\%).

Finally, several questions were posed in order to reveal Gen Z-ers' attitude towards their professional future, thus answering the third question of this study, [3] How do they project their professional life?

Looking at the Gen Z-ers' expectations regarding their career perspectives over the years, most of the respondents of this exploratory study reported expecting to work for 2 to 6 companies in their entire professional life. Robert Half stated that working for 4 companies aligns to their expectations (Half, 2015). Those who think they will work for only 1 company 
account for $7 \%$, equivalent to those expecting to work for more than 10 entities. It is to be noted that the respondents who wish to or already have entrepreneurial or freelancing careers had a separate item to choose from ("None, I am going my own way").

Furthermore, $50 \%$ of respondents expect to switch between 2 and 6 job types throughout their career, contrary to what other studies found - around 17 different jobs in a McCrindle study (2018). 17\% of Gen Z-ers reported intending to stick with the same job type, whether in the same company or not. The question referred to a job type, not a specific position within a company.

Gen $\mathrm{Z}$ members who answered this questionnaire are almost evenly divided in their opinion whether they will work harder than their parents in order to achieve career success$49 \%$ agree with this statement, $51 \%$ disagree with it. Half's study found the "yes" opinion to be the majority one, at $77 \%$ (Half, 2015).

Another item of the same question sought to measure Gen Z's opinion regarding the need for continuous improvement and lifelong learning when it comes to career success. Almost all of the respondents agree to this statement, in line with what other researchers have found (Jenkins, 2015b; Iorgulescu, 2016; Patel, 2017; Accounting Principals, 2017).

When it comes to career success, this study asked the respondents to rank at least 3 items in order of importance, starting with the first as the most important, out of 9 items in total. More than half chose "liking what they do" as the most valuable criterion, $12 \%$ ranked the size of the income in first place, and a professional skill was ranked on the top by $14 \%$ of respondents. Interestingly, $20 \%$ of respondents ranked effecting an impact through their profession on second place.

\section{Graph 4. How confident are you in your career success?}

I am reserved, I believe it is going to be hard

I am optimistic and think I am going to achieve what I hope...

I believe my career is going to be $\mathrm{OK}$

I am very concerned for my future

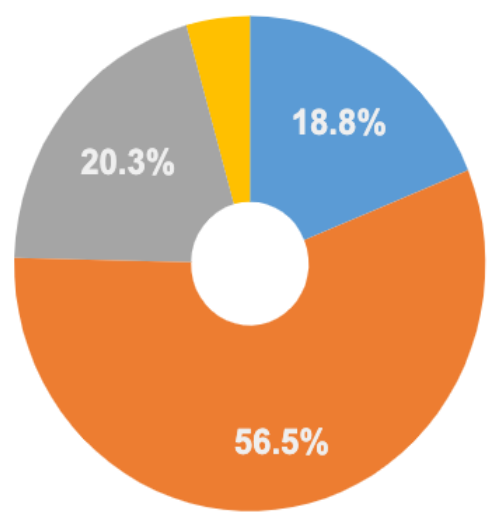

Another question evaluated the general confidence level of Gen Z-ers about their eventual career success (see Graph 4). Over half of respondents are very optimistic about it, while almost $19 \%$ among them tend to doubt a favourable outcome, being concerned about their difficult journey.

\section{Conclusions}

As this exploratory study concludes, Gen Z-ers proved to be pragmatic, valuing both job security and financial rewards right from the outset of their career, while not being in a hurry to take leadership positions. They have a pronounced appetite for mastering new skills, as they regard learning opportunities and being mentored on the job as extremely important. 
Gen Z-ers choose jobs that suit them, being concerned about effecting an impact through their career. They wish to work for corporations, rather than small companies, although a significant percentage declared they were inclined towards jobs in the public sector. Interestingly, they wish to have their own enclosed workspace, despite the setup many offices currently have, and would gladly work both on site and remotely.

The members of Gen $\mathrm{Z}$ greatly value the opportunity to bond with co-workers in a relaxed, informal environment, and may prove more tolerant than previous generations, seeing that they would enjoy having co-workers of different nationality or race.

When it comes to their perspectives of their entire career, more than half of the respondents are optimistic, and think they are going to work for 2-6 companies throughout their professional life.

This exploratory study opens the path to more in-depth and representative research concerning the expectations of Gen Z-ers upon entering the labour market, as it has the potential to challenge the current beliefs about the new wave of young professionals.

\section{REFERENCES}

Accounting Principals (2017). Generation Optimization. Strategies for recruiting, retaining and inspiring a multigenerational workforce. www.accountingprincipals.com

Adecco (2015). Generation Z vs Millennials. https://www.adeccousa.com/employers/resources/generation-Z-vsmillennials-ebook/

Arnett, J.J. (2004). Emerging Adulthood: The Winding Road from the Late Teens Though the Twenties, Oxford University Press.

Bartold, P. M. (2015), Talkin' 'bout my Generation. Aust Dent J, 60: 425.

Bicchieri, C. (2017). Scripts and Schemas. Coursera - Social Norms, Social Change II. https://www.coursera.org/learn/change/lecture/3m1nZ/9-5

Black, A. et. al. (2017). 8 key truths about generation Z. Guardians of the future and valuable consumers too. https://www.researchworld.com/8-key-truths-about-generation-z/

CIGNA U.S. (2018). Loneliness Index National Report, Cigna Intellectual Property, Inc.

Ariely, D. (2008). Predictably Irrational: The Hidden Forces That Shape Our Decisions. NY: HarperCollins. New York. ISBN 978-0-06-135323-9.

Davies, A. et. al. (2011). Future Work Skills 2020. Institute for the Future for University of Phoenix Research Institute, Palo Alto.

Ernst \& Young (2017). Barometrul încrederii angajaților români în companii. Studiu EY în Parteneriat cu HIPO

Fedock, B. (2017). Online Dissertation Chairs'Perceptions on the Role of Reflective Mentoring Practices and Changing Student Cross-Cultural and Generational Worldviews. SAGE Open. 7. 215824401770542. $10.1177 / 2158244017705421$.

Gratton, L., Scott, A. (2016). The 100-Year Life: Living and Working in an Age of Longevity. Bloomsbury.

Half, R. (2015). Get Ready for Generation Z. Robert Half International Inc.

Hamill, R.; Wilson, Timothy D.; Nisbett, Richard E. (1980). Insensitivity to sample bias: Generalizing from atypical cases (PDF). Journal of Personality and Social Psychology. 39 (4): 578-589. doi:10.1037/00223514.39.4.578. Archived from the original on 2016-05-11.

Hecklau, F. et al. (2016). Holistic approach for human resource management in Industry 4.0, 6th CLF - 6th CIRP Conference on Learning Factories, Elsevier B.V.

Iorgulescu, M. (2016), Generation Z and Its Perception of Work, CrossCultural Management Journal, issue 1, p. 47-54, https://EconPapers.repec.org/RePEc:cmj:journl:y:2016:i:9:p:47-54.

Jenkins, R. (2015a). Who is Generation Z: Understanding what matters most to the post-millennial generation? https://blog.ryan-jenkins.com/2015/06/04/who-is-generation-z-understanding-what-matters-most-tothe-post-millennial-generation

Jenkins, R. (2015b). 15 Aspects that highlight how Generation $Z$ is different from millennials. https://www.business2community.com/social-data/15-aspects-that-highlight-how-generation-z-isdifferent-from-millennials-01244940

Kane, L. (2017). Meet Generation Z, the 'millennials on steroids' who could lead the charge for change in the US. Business Insider. https://www.businessinsider.com/generation-Z-profile-2017-9

Kantar Millward Brown (2017). AdReaction Gen X, Y and Z. www.millwardbrown.com 
Kingston, A. (2014). Get ready for Generation Z. They're smarter than Boomers, and way more ambitious than the Millennials. https://www.macleans.ca/society/life/get-ready-for-generation-z/

McCrindle (2018). Changing Generations. www.mccrindle.com.au

Patel, D. (2017). 8 Ways Generation Z Will Differ from Millennials in the Workplace. Forbes https://www.forbes.com/sites/deeppatel/2017/09/21/8-ways-generation-z-will-differ-from-millennialsin-the-workplace/\#6ea456776e5e

Ronnie, L. (2017). You shouldn't be worried about Generation Z entering the work force - here's why. https://www.businessinsider.com/dont-worry-about-generation-z-entering-the-work-force-2017-7

Schwartz, J. et. al. (2017). Rewriting the rules for the digital age. Deloitte Global Human Capital Trends, Deloitte Development LLC

Tulgan, B. (2013). Meet Generation Z: The second generation within the giant "Millennial" cohort. Bruce Tulgan and RainmakerThinking, Inc.RainmakerThinking, Inc.125. New Haven

Tversky, A. \& Kahneman, D. (1974). Judgement under uncertainty: Heuristics and biases. Science. 185 (4157): 1124-1131.

Twenge, J. (2010). A Review of the Empirical Evidence on Generational Differences in Work Attitudes. Springer Science+Business Media, LLC. J Bus Psychol (2010) 25:201-210.

Twenge, J. \& Park, H. (2017). The Decline in Adult Activities Among U.S. Adolescents, 1976-2016. Child Development. 90. 10.1111/cdev.12930.

Villa, D. \& Dorsey, J. (2017). The State of Gen Z 2017: Meet the Throwback Generation. The Center for Generational Kinetics LLC.

Weller, C. (2017). A 40-year study of teens finds Generation $Z$ is unlike any past generation - here's what they're all about. https://www.businessinsider.com/generation-z-teens-what-theyre-all-about-2017-9

William, D. (2016). Millennials vs Generation Z: What Employers Must Know. https://smallbiztrends.com/2016/07/millennials-vs-generation-z.html 